\title{
ANALYSIS OF LAND USE AND LAND COVER CHANGES IN IKOT ABASI COASTAL AREA FROM 1986-2016, SOUTHERN NIGERIA, USING LANDSAT TM AND ETM+ IMAGES AND GIS
}

\author{
Iberedem E. Uko ${ }^{1 *}$, Raphael A. Offiong ${ }^{2}$ \\ *INigeria Erosion and Watershed Management Project (NEWMAP) Akwa Ibom State \\ ${ }^{2}$ Department of Geography and Environmental Science University of Calabar, Calabar
}

*Corresponding Author: -

Email ID - iberedemuko1@gmail.com,08165389141

\begin{abstract}
Ikot Abasi coastal area in Southern Nigeria, have witnessed enormous human activities which include commercial agriculture, industrial activities and urban development over the decades. Due to increasing land use in different dimensions the land cover in the area has been affected. This necessitated the gathering of land use and land cover statistically-based information which is the basis for monitoring and planning of sustainable coastal area management. This study was carried to quantitatively describe changes of land use and land cover in Ikot Abasi coast, Akwa Ibom State, from 1986 to 2016 using Landsat TM and ETM+ of the area, 1986 and 2013; and to carry out change detection in land cover between 1986-2016 in the study area. Image processing and change detection analysis were done through image interpretation processes using Erdas Imagine 9.2 software, and image Minus Algorithm of the mathematical Toolbox within ArcGIS 9.2 software respectively. Statistics indicated that out of 32,452.91ha area of land cover in 1986, the portion of land cover that has changed between 1986-2016 stood at 19,094.84ha (57.96\%), while the portion of land cover that remain unchanged within that period was only 13,849.59ha (42.03\%). With increasing human activities, more hectares of land cover are anticipated to be reduced in coming years. The study therefore, recommended sustainable agricultural practices such as bush fallowing, non-bush burning practice and selective tree cutting and implementation of development that is ecologically sustainable.
\end{abstract}

Keywords: - Land use, Land cover Change, Ecological, sustainable

\section{(a) $(\$)$}




\subsection{INTRODUCTION}

Identifying the earth's land cover as well as how we exploit the land (land use) presents the best way for monitoring and management of the earth's natural resources. Land use and land cover change (LULCC) is the conversion of different land use types and is the result of complex interactions between humans and the physical environment (Pielke, Pitman, Niyogi, Mahmood, McAlpine, and Hossain, et al. 2011). LULCC is a major driver of global change and has a significant impact on ecosystem processes, biological cycles and biodiversity (Behera, Borate, Panda, Behera and Roy 2012). Researches have shown that vast areas of the earth's terrestrial surface have undergone LULCC (Galicia and Garcia-Romero, 2007; Scanlon, Reedy, Stonestrom, Prudic, Dennehy, 2005) and with rapid economic development, land uses change more rapidly.

Various techniques of LULC change detection analysis were discussed by Lu, Mausel, Brondízio, Moran, 2004. It is possible to establish a model to predict the trends in land uses in a certain period of time through the study of past land use changes, which could provide some basis for scientific and effective land use planning, management and ecological restoration in a study area and guidance for regional socioeconomic development. Therefore, accurate and up-to-date land cover change information is necessary for understanding and assessing LULC changes. Remote sensing images can effectively record land use situations and provide an excellent source of data, from which updated LULC information and changes can be extracted, analyzed and simulated efficiently through certain means (Singh, Laari, Mustak, Srivastava, Szabó, 2017).

Land use and land cover change has become a central and important component in current strategies for managing natural resources and monitoring environmental changes. The use of remotely sensed data made it possible to study changes in land cover in less time, at low cost and with better accuracy (Kachhwala, 1985) and with Geographic Information System (GIS) which provides a suitable platform for data analysis, update and retrieval (Star, Estes and McGwire 1997; Chilar, 2000). There are different approaches to examine the changes between two fixed dates, (Lu et al., 2004). Methods for remote-sensing classification are grouped into supervised and unsupervised classifiers based on the training process; parametric (statistical) and nonparametric (non-statistical) classifiers based on their theoretical modelling considering the type of distribution of data (Aurelie et al., 2013). Remote sensing is widely used in the detection and monitoring of land use at different scales (Olokeogun, Iyiola, Iyiola, 2014; Rai, Vishwakarma, Thakur, Kamal, Mukherjee, 2016; Mishra, Rai, Kumar, Prasad, 2016; Offiong, Offiong and Ekpe, 2014). GIS provides a flexible environment for collecting, storing, displaying and analyzing digital data necessary for change detection (Reis, 2008; Mishra et. al., 2016; Offiong, Offiong and Ekpe, 2014).

The aim of this study is first, to quantitatively describe spatio-temporal changes of land use and land cover in the coastal area of Ikot Abasi from 1986 to 2013 using Landsat imagery of the area, 1986 and 2013; and secondly, to carry out change detection in land cover between 1986-2013 in the study area. Justifying the choice of the two years for this study, year 1986 was selected as the base year since Akwa Ibom State was created a year after (1987), while 2013 account for a recent data availability. In order to create subset images of the study area prior to actual enhancement and classification procedures, layer stacking and area of interest (AOI) tools were applied to images. The analysis provides a basis for better control of human impacts and enhances sustainable use of coastal resources activities in this coastal area for the general well-being of both man and the society.

Nigeria Niger Delta region is known for unprecedented land use activities which have negative effects on the land cover in the entire region. Research by Uko (2016) conducted on the impacts of mangrove forest depletion on community livelihood in Ikot Abasi coastal area revealed agriculture, industrialization, urbanization and exploitation of natural resources as sets of land use which have consequential effects on land cover. Despite the negative effects on land covers, there is continuous destruction of land covers in Ikot Abasi (Uko, 2016). Unfortunately, there is limited up-to-date data on the status of land cover changes aggravated by land use in the area and this makes monitoring and planning of sustainable coastal area management difficult for Ikot Abasi coastal area the study concludes. The quantitative data gathered in this study can drive the formulation of regulations for the protection of the remaining land covers and promote sustainable utilization. It is based on this premise that this research was embarked to investigate land use and cover changes in Ikot Abasi coastal area from 1986-2016, in Akwa Ibom State, Nigeria, using Landsat TM and ETM+ images.

\section{0 study area}

Ikot Abasi Local Government Area is a coastal area situated in the South Western-part of Akwa Ibom State, Southern Nigeria. It is situated between latitudes $4^{0} 28^{\prime}$ and $4^{0} 43^{\prime} \mathrm{N}$ and longitude $7^{0} 30^{\prime}$ and $7^{0} 50^{\prime} \mathrm{E}$, with an area cover of approximately $451.727 \mathrm{~km}^{2}$ (Udo, Asuquo \& Asuquo, 2001). The climate is humid-tropic and temperatures between $26^{\circ} \mathrm{C}$ and $28^{\circ} \mathrm{C}$ and mean annual rainfall of the area is between 2,500-4,000 mm. The rainy season starts from April and ends by November, while the dry season starts from November and ends in March with Harmattan experienced between December and January. The area is flat and low-lying, with three major terrains, namely, the alluvial plains which comprises of mangrove and flood plains, the beach ridge sands and the rolling sandy plains. The soils in the area are formed mainly from the coastal plain sands and the beach bridge sands parent materials (Udoh \& Chukwu, 2014). The human population of Ikot Abasi Local Government Area has risen from 66,160 in 1991 to 132,023 in 2006 (National Population Commission, 1991; 2006). 


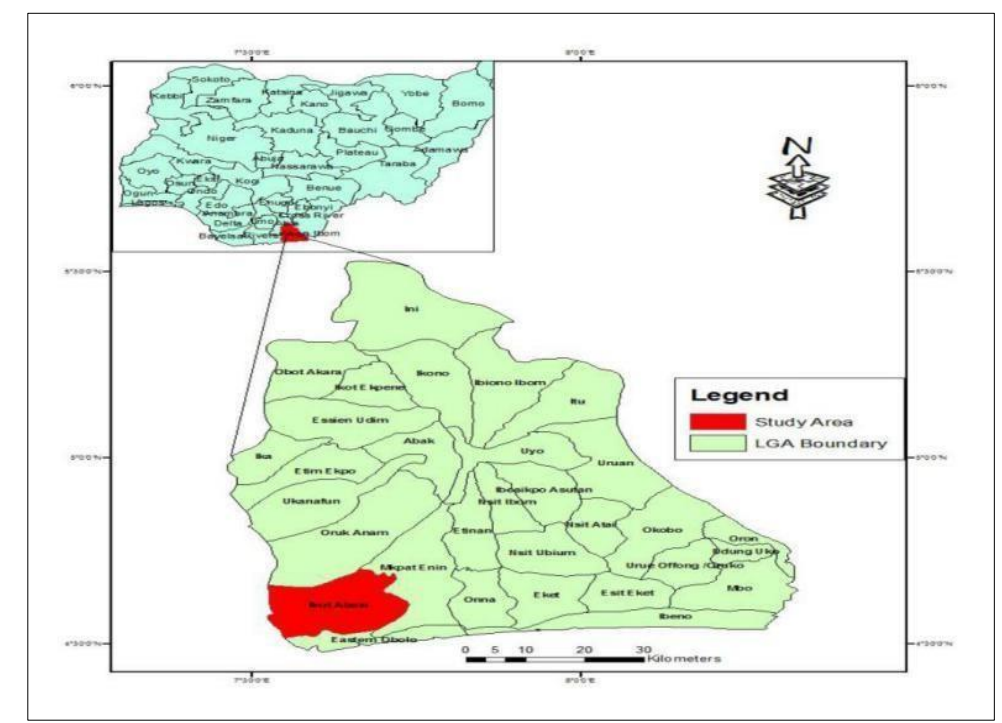

Fig.1: Map of Nigeria showing Akwa Ibom State and the Study Area (Ikot Abasi) is marked red.

Source: Produced by Authors using QGIS

\section{0 methodology}

3.1 geographic information system (gis) technology and remote sensing application

The Geographic information system (GIS) technology and remote sensing application were used to determine the trend of mangrove forest change from 1986 to 2016. Landsat TM and ETM+ images captured in December 1986 and January 2013 were acquired from the United States Geological Survey (USGS), with each having a spatial resolution of approximately $28.5 \mathrm{~m}^{2}$. An existing land use/cover map of the area acquired from Cross River Basin Development Authority (CRBDA) was also used as ancillary data for accuracy assessment of the 1986 classified image. Also, randomly selected Geographic Positioning System (GPS) points were collected and utilized for the accuracy assessment of the 2013 land use data.

\subsection{Land use classification scheme (LUCS)}

Ikot Abasi Local Government Area, Akwa Ibom State is a part of the Cross-River basin located within the mangrove swamp forest belt of southern Nigeria. Extensive land use and vegetation mapping had previously been undertaken by the CRBDA. In this work, reference was made to the land use and vegetation classification scheme which the Authority used when mapping the area in 1987.For the purpose of this study, four land use/cover classes were used which are compound farmland, bush fallow, mangrove swamp forest and water bodies.

\subsection{Image processing}

Figure 2 below shows the steps involved in image processing and change detection analysis. All the image interpretation processes were carried out using Erdas Imagine 9.2 software, while change detection aspects were completed using the image Minus Algorithm of the mathematical Toolbox of the Spatial Analyst extension within ArcGIS 9.2 software. Erdas Imagine was used due to its robust and advance image analysis functionalities, while the use of ArcGIS was prompted by its flexibility in spatial data handling and analysis. 


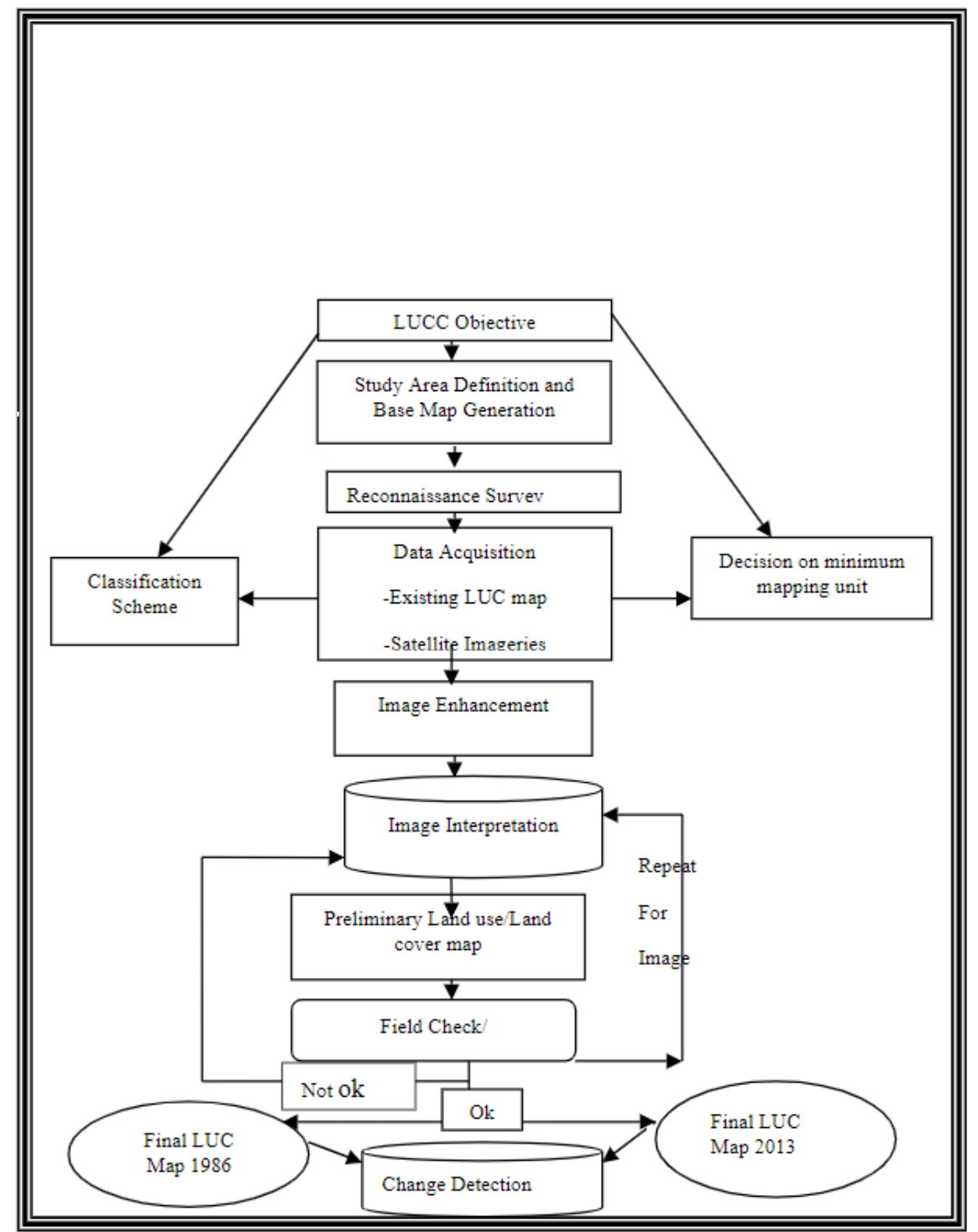

FIG. 2: Schema for image processing

Source: Ituen, Whyatt, Blackburn \&Inyang, 2008

\subsection{Change detection}

There were two forms of spatial analyses undertaken namely: area calculation of the land use/cover for each year and post-classification change detection. The former involves comparison of the LUC statistics derived from the classified images, while the latter is an area-specific change detection procedure (point-by-point). With these two techniques, information on the nature, location, magnitude, trend and rate of change were highlighted. Weismiller, Kerstof, Scholz, Anita \& Koming (1977) considers this point-by-point method superior to other change detection techniques within image analysis systems, it helps to maintain a finer control over the data sets and offers greater flexibility in generating related classes of change.

\section{0 results and discussion}

\section{1 land cover/use change between 1986 to 2016 in ikot abasi lga}

Table 4.1 shows the changes in land cover/use of different classes in Ikot Abasi from 1986 to 2016. Mangrove forest in the study area was reduced from 5,382.91 ha (1986) (FIG.3) to 5,210.00ha (2001) and further reduced to 5,038.61ha (2016) (FIG.4), with a total area of change being 343.1ha within 1986-2016 and annual change rate of 11.07ha. The reduction in area cover was attributed to industrial development where large hectares of mangrove were destroyed making way for building of industries and estates.

Open water, another class of land cover, was reduced from 1,248.02ha (1986) (FIG.3) to 1,244.21ha (2001) and further reduced to 1,241.46ha (2016) (FIG.4), with a total area of change being 6.58ha within 1986-2016 and annual change rate of $0.21 \mathrm{ha}$. The loss of open water in the area was attributed to land use activities such as sand mining, dumping of waste, and extension of farmland to the streams, among others.

Also, bush fallow was reduced from 17,145.53ha (1986) (FIG.3) to 16,153.75ha (2001) and further reduced to $15,178.08 \mathrm{ha}$ (2016) (FIG.4), with a total area of change being 1,967.45ha within 1986-2016 and have an annual change rate of 63.46ha. 
Reduction in bush fallow in the study area is attributed to extensive agriculture which involves the clearing of thick bush and forest, massive cutting down of trees and bush burning.

The changes in the different classes of land cover in Ikot Abasi was due to urban/settlement expansion, industrial development and sand mining. Ikot Abasi, home to Africa largest Aluminum Smelter Company of Nigeria (ALSCON), has witnessed unregulated sand mining which have devastated the land cover where large quantities of sand were mined to build industries and estates located in the area, and there is commercial sand mining still going on today unabated. Also, illegal oil refining in the area early 2000s led to large-scale cutting down of mangrove trees for burning of oil. During the era of this illegal oil business, oil were spilled on the surface, mangrove/forested area, rivers, streams and lakes with attendant degradation of the land covers.

Land use identified (compound farmland) was only 8,676.65ha (1986) (FIG.3) but increased to 9,798.56ha (2001) and further increased to 101,013.11ha (2016) (FIG.4), with a total area of change being 2,336.46ha within 1986-2016 and annual change rate of 75.36ha. Farming has been one of the major economies in Ikot Abasi when every households involving in agricultural practices for their livelihood and sustenance. It is very common to see large quantities of farm produces in the markets on daily basis. The area is well known for its farming activities characterized with felling down of trees, bush burning, shifting cultivation which encroached to the hinterland and thick vegetation. Bush fallowing in the area has drastically reduced due to expansive agricultural practices.

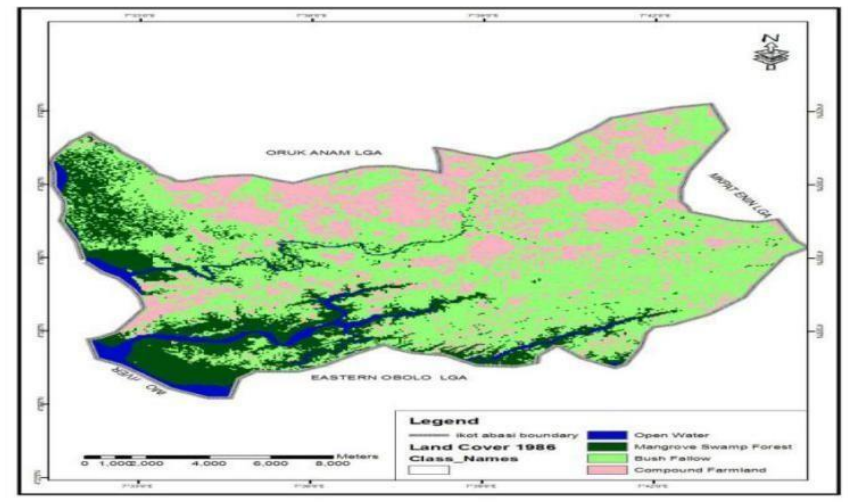

FIG. 3: Land cover map of Ikot Abasi Local Government Area in 1986

Source: GIS and Remote Sensing Laboratory, University of Uyo

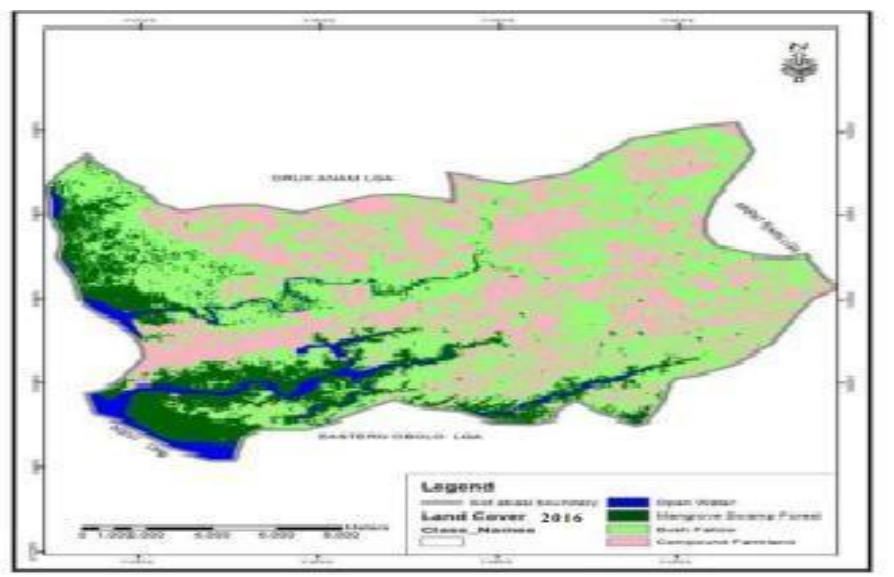

FIG. 4: Land cover map of Ikot Abasi Local Government Area in 2016

Source: GIS and Remote Sensing Laboratory, University of Uyo

\subsection{Change detection in land cover within 1986-2016 in Ikot Abasi LGA}

Table 4.2 below showed the extent of change of land cover in the study area gotten from the change detection carried out from the Landsat images used for the analysis. The change detection was classified into decreased change, increased change and unchanged. From the analysis, the area of land cover with decreased change was 8,324.32ha representing 25.27 percent. This was predominately at the northern part and was attributed to some cultural practices like bush fallowing, restriction in massive cutting down of trees among others.

The area of land cover with increased change stood at10,770.52ha representing 32.69 percent. The affected land cover is located around the southern and central parts of the area (FIG. 5) and was attributed to expanding compound farmland characterized with massive cutting down of trees, bush burning and shifting cultivation, industry's location and associated activities, settlement expansion, sand mining and other socioeconomic activities. 
Analysis showed a total of 13,849.59 hectares (representing 42.03 percent) of land cover has remained unchanged since 1986. The area of land cover that remains unchanged and stable is located at the western and south eastern flank of Ikot Abasi which is around the Imo River and its tributaries (FIG. 5). The reason was the swampy nature of this area which has helped reduced human interference, hence halt exploitation of the mangrove swamp forest.

In summary, the total portion of land cover (Table 4.2b) that has changed between 1986-2016 stood at 19,094.84ha (57.96 percent), while the portion of land cover that remain unchanged within that period was 13,849.59ha (42.03 percent).

Table 4.2a: Summary of change of land cover in the study area

\begin{tabular}{lcl}
\hline Type of change & Area of change $(\mathrm{Ha})$ & Percentage of change \\
\hline Decreased change & $8,324.32$ & $25.27 \%$ \\
Increased change & $10,770.52$ & $32.69 \%$ \\
Unchanged & $13,849.59$ & $42.03 \%$ \\
Total & $\mathbf{3 2 , 9 4 4 . 4 3}$ & $100 \%$ \\
\hline
\end{tabular}

Source: Researchers' fieldwork, 2015

Table 4.2bStatus of Land cover changed and unchanged between 1986-2013 in the study area

\begin{tabular}{lll}
\hline Status of Land cover & Area covered $(\mathrm{Ha})$ & Percentage of change \\
\hline Changed portion & $19,094.84 \mathrm{ha}$ & $57.96 \%$ \\
Unchanged portion & $13,849.5 \mathrm{ha}$ & $42.04 \%$ \\
Total & $\mathbf{3 2 , 9 4 4 . 4 3 \mathrm { ha }}$ & $100 \%$ \\
\hline
\end{tabular}

Source: Researchers' fieldwork, 2015

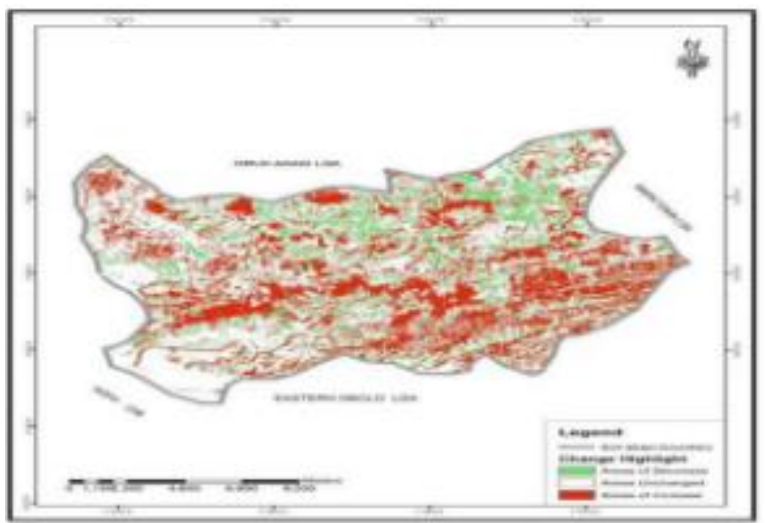

FIG. 5: Land cover change map of Ikot Abasi Local Government Area between 1986-2016Source: GIS and Remote Sensing Laboratory, University of Uyo

\section{0 conclusion}

The study identified commercial agriculture, urbanization and industrialization as sets of land use in Ikot Abasi coastal area, Akwa Ibom State, Nigeria, which have affected the land covers drastically. Typically, agricultural practices in the area is being characterized with massive cutting down of trees, clearance of forest and bush burning. Statistical analysis has shown that a total area of 19,094.84ha land cover (57.96\%) has been lost remaining just 13,849.59ha (42.03\%) within 1986-2016. With increasing human activities, more hectares of land cover are anticipated to be reduced in coming years. The study therefore, recommended sustainable agricultural practices such as bush fallowing, non-bush burning and selective tree cutting and implementation of development that is ecologically sustainable

\section{Appendix 1}

Trend of land use/ land cover changes in Ikot Abasi LGA from the periods 1986 to 2016

\begin{tabular}{|c|c|c|c|c|c|c|c|c|}
\hline Year & $\begin{array}{l}\text { Area of } \\
\text { mangrove } \\
\text { forest (ha) }\end{array}$ & $\begin{array}{l}\text { Size of } \\
\text { mangrove } \\
\text { forest loss } \\
\text { (ha) }\end{array}$ & $\begin{array}{l}\text { Area of } \\
\text { surface water } \\
\text { (ha) }\end{array}$ & $\begin{array}{l}\text { Size of open } \\
\text { water } \\
\text { loss (ha) }\end{array}$ & $\begin{array}{l}\text { Area of bush } \\
\text { fallow } \\
\text { (ha) }\end{array}$ & $\begin{array}{l}\text { Size of bush } \\
\text { fallow loss } \\
\text { (ha) }\end{array}$ & $\begin{array}{l}\text { Area of } \\
\text { compound } \\
\text { farmland } \\
\text { (ha) }\end{array}$ & $\begin{array}{l}\text { Size of land cover } \\
\text { loss to compound } \\
\text { farmland (ha) }\end{array}$ \\
\hline 1986 & $5,382.71$ & 0 & $1,248.02$ & 0 & $17,145.53$ & 0 & $8,676.65$ & 0 \\
\hline 1989 & $5,349.59$ & 33.12 & $1,247.34$ & 0.68 & $16,956.23$ & 189.30 & $8,899.61$ & 222.96 \\
\hline 1992 & $5,315.53$ & 34.06 & $1,246.61$ & 0.73 & $16,747.48$ & 208.75 & $9,122.71$ & 223.1 \\
\hline 1995 & $5,280.24$ & 35.29 & $1,245.91$ & 0.70 & $16,537.39$ & 210.09 & $9,345.94$ & 223.23 \\
\hline 1998 & $5,245.24$ & 35.00 & $1,245.21$ & 0.70 & $16,345.71$ & 191.68 & $9,571.39$ & 225.45 \\
\hline 2001 & $5,210.00$ & 35.24 & $1,244.52$ & 0.69 & $16,153.75$ & 191.96 & $9,798.56$ & 227.17 \\
\hline 2004 & $5,175.86$ & 34.14 & $1,243.84$ & 0.68 & $15,960.69$ & 193.47 & $10,038.16$ & 239.60 \\
\hline 2007 & $5,141.32$ & 34.54 & $1,243.16$ & 0.68 & $15,766.69$ & 193.59 & $10,277.85$ & 239.69 \\
\hline 2010 & $5,107.79$ & 33.53 & $1,242.5$ & 0.66 & $15,570.72$ & 195.97 & $10,518.13$ & 240.28 \\
\hline 2013 & $5,074.61$ & 33.18 & $1,241.96$ & 0.54 & $15,378.68$ & 192.04 & $10,757.71$ & 239.58 \\
\hline 2016 & $5,039.61$ & 35.00 & $1,241.46$ & 0.52 & & 200.60 & $11,013.11$ & 255.40 \\
\hline $\begin{array}{l}\text { Change from } \\
1986 \text { to } 2016 \text { (ha) }\end{array}$ & & 343.1 & & 6.58 & & 1967.45 & & 2336.46 \\
\hline Change per Year & & 11.07 & & 0.21 & & 63.46 & & 75.36 \\
\hline
\end{tabular}

Source: GIS and Remote Sensing Laboratory, University of Uyo, Uyo 


\section{References}

[1].Aurelie, V., Vladimir, K., Gabriele, M., Sebastiano, S. \& Josiane, Z. (2014). Supervised Classification of Multi-sensor and Multi-resolution Remote Sensing Un-eyes with a Hierarchical Copula-based Approach. Institute of Electrical and Electronic Engineers (IEEE), 52 (6):3346-3358.

[2].Behera, M. D; Borate S. N; Panda S. N; Behera, P. R.. \& Roy, P. S. (2012). Modelling and analyzing the Watershed Dynamics using Cellular Automata (CA)-Markov model-A geo-information based approach. J. Earth Syst. Sci.121(4):1011-24.

[3].Chilar, J. (2000). Land Cover Mapping of Large Areas from Satellites: Status and Research Priorities. International Journal of Remote Sensing 21(67):1093-1114.

[4].Galicia, L. \& Garcia-Romero, A. (2007). Land Use and Land Cover Change in Highland Temperate Forests in the Izta-Popo National Park, central Mexico. Mt Res Dev.,27(1):48-57.

[5].Ituen, U. J., Whyatt, J. D., Blackburn, G.A. \& Inyang, I. B. (2008). Land Use/ Cover Change and Agricultural Practices in the Tropical Environment of Northern Akwa Ibom State, Nigeria. $14^{\text {th }}$ International Symposium on Implementation of Landscape Ecology in New and Changing Conditions, Stara Lana, October 4-7, 2008.

[6].Kachhwala, T. S. (1985). Temporal Monitoring of Forest Lands for Change Detection and Forest Cover Mapping through Satellite Remote Sensing. In: Proceedings of the $6^{\text {th }}$ Asian Conference on Remote Sensing, Hyderabad, $77-$ 83.

[7].Lu, D., Mausel, P., Brondízio, E. \& Moran, E. (2004). Change Detection Techniques. Int J Remote Sens., 25(12):2365401.

[8].Mishra, V. N., Rai, P. K., Kumar, P. \& Prasad, R. (2016). Evaluation of Land Use/Land Cover Classification Accuracy using Multi-resolution Remote Sensing Images. Forum geografic., XV(1):45-53.

[9].National Population Commission, Census 1991. National Population Commission, Census 2006.

[10]. Offiong, R. A., Offiong, V. E. \& Ekpe, I. A. (2014). Effect of Land Cover Change on Fresh Water Ecosystem in Calabar Municipality, Cross River State, Nigeria. International Journal of Physical and Human Geography, 2(1):2736.

[11]. Offiong, R., Ukpong, I. \& Uko, I. E. (2017). Impacts of Mangrove Forest Depletion on Community Livelihood in the Imo River Basin, Akwa Ibom State, Nigeria. In: Proceedings of the 2017 Annual Conference of Environmental Management Association of Nigeria, held in Port-Harcourt, Rivers State, Nigeria, December 6-9, 2017.

[12]. Olokeogun, O. S., Iyiola, K. \& Iyiola, O. F. (2014). Application of Remote Sensing and GIS in Land Use/Land Cover Mapping and Change Detection in Sahara Forest Reserve, Nigeria. ISPRS-Int Arch Photogramm, 8(8):613-6.

[13]. Pielke, R. A; Pitman, A; Niyogi, D; Mahmood, R; McAlpine, C. \&Hossain, F, et al. (2011). LandUse/Land Cover Changes and Climate: Modeling Analysis and Observational Evidence. Wires Clim Change,2(6):828-50.

[14]. Rai, P. K., Vishwakarma, C. A., Thakur, S., Kamal, V. \& Mukherjee, S. (2016). Changing Land Trajectories: A Case Study from India Using a Remote Sensing Based Approach. European Journal of Geography, 7(2):63-73.

[15]. Reis, S. (2008). Analyzing Land Use/Land Cover Changes Using Remote Sensing and GIS in Rize, North-East Turkey. Sensors, 8(10):6188-202.

[16]. Scanlon, B. R., Reedy, R. C, Stonestrom, D. A., Prudic, D. E. \& Dennehy, K. F. (2005). Impact of Land Use and Land Cover Change on Groundwater Recharge and Quality in the Southwestern US. Glob Change Biol., 11(10):1577-93.

[17]. Singh, S. K., Laari, P. B., Mustak, S., Srivastava, P. K. \& Szabó, S. (2017). Modelling of Land Use/Land Cover Change using Earth Observation Data-sets of Tons River Basin, Madhya Pradesh, India. Geocarto:1-34.

[18]. Star, J. L., Estes, J. E. \& McGwire, K. C. (1997). Integration of Geographic Information Systems and Remote Sensing. New York: Cambridge University Press.

[19]. Udo, E. J., Usen, A. M.. \& Asuquo, J. E. (2001). Assessment of Environmental Problems of Ikot Abasi Local Government Area. Pam Scientific Laboratories, Uyo, Nigeria, 60p.

[20]. Udoh, B. T. \& Chukwu, E. D. (2014). Pos-Impact Assessment of Oil Pollution in some Soil Characteristics in Ikot Abasi, Niger Delta Region, Nigeria. Journal of Biology, Agriculture and Healthcare, 4(24):111-119.

[21]. Uko, I. E. (2016). Impacts of Mangrove Forest Depletion on Community Livelihood in Ikot Abasi Local Government Area, Akwa Ibom State, Nigeria. Unpublished M.sc. Thesis submitted to the Department of Geography and Environmental Science, Faculty of Social Science, University of Calabar, Calabar.

[22]. Weismiller, R. A., Kerstof, S. J., Scholz, D. K., Anita, P. E. \& Koming, S. A. (1977). Change Detection in Coastal Zone Environments. Photogrammetric Engineering and Remote Sensing, 43, 1533-1539. 